\title{
A Response to "Depression and Anxiety Among Medical Students: A Brief Overview." - The Issue of Stigmatisation in the Medical Profession [Letter]
}

\section{Anushka Sharma (D) \\ Imperial College School of Medicine, Imperial College London, London, UK}

Correspondence: Anushka Sharma Imperial College School of Medicine, Imperial College London, London, UK Tel +44 7427404I35

Email as7316@ic.ac.uk

\section{Dear editor}

I read, with great interest, the article by Mirza et al reviewing the prevalence of depression and anxiety amongst medical students, and the psychological wellbeing of this population. ${ }^{1}$ As a medical student, I am familiar with the endemic nature of depression and anxiety amongst young people, and empathise with those who feel reluctant to confide in their peers and colleagues.

The authors highlighted the increase in prevalence of mental health disorders amidst medical students, and offered personal, psychosocial and university-related factors associated with depression and anxiety, including aspects of the university course. However, the authors were hesitant to discuss the reasons for such increases in rates of mental ill-health, and did not adequately address the obstacles that prevent medical students from accessing adequate mental health support during university.

One such obstacle is the stigmatisation of mental illness. ${ }^{2}$ Medical students and doctors have alluded to the idea that stigmatising attitudes are not only attributed towards mental illness by wider society, but are reinforced within the medical profession. ${ }^{3}$ Such stigmatising attitudes have negative consequences on the wellbeing of healthcare professionals and contribute to the unwillingness of this population to seek help.

Henderson et al described the phenomenon of "self-stigma", whereby those who perceive stigma adopt and internalise external social stigma. ${ }^{4}$ As a result, they experience a reduction in self-esteem and self-efficacy. It has been postulated that, because there exists the unattainable notion of "invincibility" amongst medical students and doctors, any degree of vulnerability feels anomalous. It then follows that, feelings of susceptibility are not in keeping with the core values of the profession, and suppression of such feelings is encouraged by the individual. ${ }^{2,4}$ This is a vicious cycle that perpetuates self-stigma and threatens the psychological wellbeing of those experiencing it. Fears of exposure to stigmatisation result in low levels of help seeking amongst medical students and doctors for mental health problems, and have meant that this population present to mental healthcare services only in crises. ${ }^{5}$

The issue of stigmatisation of mental illness is pervasive within society and the medical profession is no exception. For as long as the cycle of self-stigma is 
allowed to propagate, the prevalence of mental health disorders, such as depression and anxiety, will increase. ${ }^{1}$

It has been demonstrated that an imperative aspect of preventing further increases in the rates of mental health compromise amongst medical students and doctors is a reduction in the impact of stigma. ${ }^{5}$ Antistigma work within universities may facilitate the empowerment of individuals for whom mental illness has burdened their educational experience and impacted their lives. Consequently, it is crucial that the authors of research papers pertaining to the mental ill-health of medical students explore the presence of stigma in modern-day medical education, evaluate the efforts of pastoral-led initiatives within universities to discourage stigmatising behaviours, and discuss whether the existence of stigma still impacts the likelihood of help-seeking amongst medical students.

\section{Disclosure}

The author reports no conflicts of interest in this communication.

\section{References}

1. Mirza AA, Baig M, Beyari GM, Halawani MA, Mirza AA. Depression and anxiety among medical students: a brief overview. $A d v$ Med Educ Pract. 2021;12:393-398. doi:10.2147/AMEP.S302897

2. Hankir AK, Northall A, Zaman R. Stigma and mental health challenges in medical students. BMJ Case Rep. 2014;2014: bcr2014205226-bcr2014205226. doi:10.1136/bcr-2014-205226

3. Brower KJ. Professional stigma of mental health issues: physicians are both the cause and solution. Acad Med. 2021;96(5):635-640. doi:10.1097/ACM.0000000000003998

4. Henderson M, Brooks SK, Del Busso L, et al. Shame! Self-stigmatisation as an obstacle to sick doctors returning to work: a qualitative study. BMJ Open. 2012;2:e001776. doi:10.1136/bmjopen2012-001776

5. Semple D, Smith R. Oxford Handbook of Psychiatry. 2nd ed. Oxford: Oxford University Press; 2008:279-317.

Dove Medical Press encourages responsible, free and frank academic debate. The content of the Advances in Medical Education and Practice 'letters to the editor' section does not necessarily represent the views of Dove Medical Press, its officers, agents, employees, related entities or the Advances in Medical Education and Practice editors. While all reasonable steps have been taken to confirm the content of each letter, Dove Medical Press accepts no liability in respect of the content of any letter, nor is it responsible for the content and accuracy of any letter to the editor.

\section{Publish your work in this journal}

Advances in Medical Education and Practice is an international, peerreviewed, open access journal that aims to present and publish research on Medical Education covering medical, dental, nursing and allied health care professional education. The journal covers undergraduate education, postgraduate training and continuing medical education including emerging trends and innovative models linking education, research, and health care services. The manuscript management system is completely online and includes a very quick and fair peer-review system. Visit http://www.dovepress.com/testimonials.php to read real quotes from published authors. 